\title{
FINANCIAL RESULTS ACHIEVED IN SHORT-DAY STRAWBERRY PRODUCTION
}

\author{
Dragan Galić1, Dušan Milič², Zorica Sredojevićc ${ }^{3}$
}

\section{Summary}

In South-western Ontario's continental climate (short days, hot summers and very cold winters) the matted-row system was the dominant production system to grow short-day strawberries. Varieties-staggered production (planting a combination of early, mid and late-season varieties) provides strawberry harvest from five to seven weeks. Short-day strawberries are vegetative grown in the first year, and harvested for two consecutive years. The total cost of short-day strawberry production was 54,370 \$CAD/ha. The production and harvest costs in the first and second years were 20,812 \$CAD/ha and 16,930 \$CAD/ ha, respectively, and accounted for $69.42 \%$ of the total. Pre-plans operations were the least expensive procedures costing $8.13 \%$, while planting and care of young plants made up 22.45\% of the total costs. The total income of growing short-day strawberries under a matted-row system was 76,671 \$CAD/ha (the first and second production years 41,330 $\$ C A D / h a$ and 35,341 \$CAD/ha, respectively). The short-day strawberries in matted-row system, with average yield of $15,722 \mathrm{~kg} / \mathrm{ha}$, generated a net revenue of 22,300 \$CAD/ha.

Key words: short-day of strawberry, cost of production, total income, and financial result.

JEL: $Q 12, Q 13, P 42$

\section{Introduction}

Cultivated strawberry (Fragaria $\mathrm{x}$ ananassa Duch.) is a perennial plant, with compressed stem and shallow root system, derived from two North American species Fragaria virginiana Duch. and Fragaria chiloensis (L) Duch. (Darnell et al., 2003). Based on the volume of world's production, variety of fruits use, uniqueness of aroma and flavor and earliness, strawberries are the most grown small fruit specie. Strawberry is highly prized

1 Dragan Galić, M.Sc., University of Guelph, Department of Plant Agriculture, Box 587, Simcoe, N3Y 4N5, ON, Canada, Phone: 00151942822 45, E-mail: dgalic@uoguelph.ca

2 Dušan Milić, Ph.D., Full Professor, University of Novi Sad, Faculty of Agriculture, Trg Dositeja Obradovića Street no. 8, 21000 Novi Sad, Serbia, Phone: +381 21485 32 30, E-mail: milic@polj.uns.ac.rs

3 Zorica Sredojević, Ph.D., Full Professor, University of Belgrade, Faculty of Agriculture, Department of Agroeconomy, Nemanjina Street no. 6, 11080 Belgrade, Serbia, Phone: +381 11 2615 315, E-mail: zokas@agrif.bg.ac.rs

EP 2014 (61) 4 (851-859) 
since harvest is early in a season (the harvest of short-day strawberries is in following year after panting, while harvest of day-neutral strawberries is in a planting year) and very high yields. This crop is also very valuable for fresh consumption and processing industry (Milić et al., 2008; Milić, Sredojević, 2010).

The latest research suggests that supplementary diets of strawberries is associated with delays in age-related decline in neural activities and behavioral deficits, ant carcinogenic activities in breast and cervix cells and significant reduction in negative impact of free radicals on gastric mucosa. Strawberry fruit contains large numbers of phenol acids and bioflavonoid compounds with powerful antioxidant properties (Wang, Lin, 2000).

Advances in new variety development, cropping systems and fruit marketing of short-day strawberries extended the traditional harvest season. This also initiated development and implementation of new technologies in strawberry production (Lieten, 2003; Safley et al., 2004; Ballington et al., 2008; Rowley et al., 2010; Milić, Sredojević, 2010).

Moreover, the research in day-neutral strawberry production provides a unique harvest season extension. Current and potential strawberry growers need not only relevant production and marketing information, but also precise financial information to make informed decisions about existing strawberry operation and possible expansion or new technology adoption. In addition, Pritts and Castaldi (1990) suggested that financial analyses are useful for identifying those factors which have the biggest impact on strawberry production in an environment and can help the researchers determine how best to allocate funds within research programs based on importance of variables studied.

\section{Material and methods}

The objective of this study is to examine the current technology of strawberry production in North America. The case study is short-day strawberry production under matted-row system in South-western Ontario. This study has two overall objectives. The first is to show that short-day strawberry production is profitable in Ontario. The second is to adapt current intensive short-day strawberry production technology used in Ontario to strawberry growers and researchers in Republic of Serbia and Republic of Serbian.

A survey technique was used to collect data. The survey collected data on materials, labour and machinery and equipment used for all short-day strawberry production procedures performed. Each of these procedures is divided into three groups: 1) replant; 2) establishment; and 3) harvest year procedures. The survey also collected data on yields, price achieved, and sale channels.

The survey technique was a method of choice for data collection since Canada does not have a system of accountancy data collection, such as Farm Accountancy Data Network (FADN) in Europe. It is an instrument for evaluating the income of agricultural holdings and the impacts of the Common Agricultural Policy in Europe (Sredojević, Mojsijev, 2013). The data collection was endorsed and facilitated by the Ontario Berry Grower Association (OBGA) and berry crop specialist of the Ministry of Agriculture 
and Food (OMAF) of Ontario. The OBGA suggested potential growers in Southwestern Ontario to be included in the survey. The establishment cost of strawberry production is based on average cost from 28 growers in South-western Ontario (http:// ontarioberries.com/). The average cost was calculated from analytical calculations of surveyed growers during the period 2008-2012. All calculations are expressed per hectare. This calculation model allows calculating fixed and variable expenses for all strawberry production procedures, total income and financial results achieved.

\section{Results and discussion}

Like many high-value crops, strawberry production is resource and labour-intensive and carries a high degree of risk. But also, short-day strawberry production leaves ample of additional room for profit increase. Continued interest in the crop depends on the size of returns after costs are covered. To make informed decisions a new grower needs an economic analysis of the cost of strawberry production from existing growers.

\section{Yield Achieved}

Strawberry yield is a complex trait, and is determined by an interaction of environment and inherited traits such as number and size of the fruits, plant volume and cold, pest and disease tolerance. These inherited traits define a variety. Therefore, yield is determined by variety and number of plants per area. Yield, is also affected by cultural practices, degree of the investments in production and growers knowledge and understanding of common principles of the strawberry plant.

As a high-value crop strawberries are grown on the best agricultural soils in Ontario. The main strawberry-producing areas are located in proximity to major urban centers and important transport corridors within the Great Lakes modified continental climate. According to results the largest yields are achieved in: Essex, Middlesex, Oxford, Norfolk and Brant counties, on farms located along Highway 401 and farms in the vicinity of the Greater Toronto Area.

Yields can be affected by family tradition of strawberry production, and grower's will to adopt new technologies in strawberry production. It is interesting to note that the average strawberry yields of $10,000 \mathrm{~kg} / \mathrm{ha}$ or higher were achieved on farms with good working relations with research institutions. The average yield on farms with a tradition in strawberry production was from $7,840 \mathrm{~kg} /$ ha to $16,800 \mathrm{~kg} / \mathrm{ha}$ per season (Table 1).

The lowest yields were recorded on farms with strawberries as a new crop within the production program. The survey data suggest that the main reason for yield reduction is lack of adequate weed, pest and disease management. The pesticide regime of strawberries is intensive and complex, which requires excellent knowledge of strawberry production technology to secure adequate plant protection and safe fruit. 
Table 1. The average yield per location ${ }^{1,2}$

\begin{tabular}{|c|c|c|c|}
\hline Locations & $\begin{array}{c}\text { First harvest year } \\
(\mathbf{k g} / \mathbf{h a})\end{array}$ & $\begin{array}{c}\text { Second harvest year } \\
(\mathbf{k g} / \mathbf{h a})\end{array}$ & Total \\
\hline $1^{1}$ & 16,800 & 11,200 & 28,000 \\
\hline $2^{1}$ & 13,440 & 11,760 & 25,200 \\
\hline $3^{1}$ & 8,960 & 5,600 & 14,560 \\
\hline $4^{1}$ & 11,200 & 11,200 & 22,400 \\
\hline $5^{2}$ & 2,464 & 2,016 & 4,476 \\
\hline $6^{2}$ & 3,584 & 3,248 & 7,102 \\
\hline $7^{1}$ & 6,160 & 4,620 & 10,780 \\
\hline $8^{1}$ & 8,400 & 8,400 & 16,800 \\
\hline $9^{1}$ & 6,082 & 3,808 & 9,890 \\
\hline $10^{2}$ & 6,720 & 6,160 & 12,880 \\
\hline $11^{1}$ & 6,720 & 6.720 & 13.440 \\
\hline $12^{1}$ & 15,120 & 15,120 & 30,240 \\
\hline $13^{1}$ & 13,440 & 10,080 & 23,520 \\
\hline $14^{1}$ & 8,736 & 8,400 & 17,136 \\
\hline $15^{2}$ & 7,280 & 6,160 & 13,440 \\
\hline $16^{1}$ & 13,440 & 10,080 & 23,520 \\
\hline $17^{2}$ & 6,720 & 6,160 & 12,880 \\
\hline $18^{1}$ & 7,840 & 7,840 & 15,680 \\
\hline $19^{2}$ & 6,272 & 6,272 & 12,544 \\
\hline Average & 8,915 & 7,623 & 15,722 \\
\hline
\end{tabular}

Source: Authors calculation based on survey 28 producers strawberries in South-western Ontario Note: ${ }^{1}$ Average five-year yields from the same location, but different fields from 2007 to 2012; ${ }^{2}$ Yields achieved in 2011-2012, first time strawberry growers are included in this group.

As a high-value crop strawberries are grown on the best agricultural soils in Ontario. The main strawberry-producing areas are located in proximity to major urban centers and important transport corridors within the Great Lakes modified continental climate. According to results the largest yields are achieved in: Essex, Middlesex, Oxford, Norfolk and Brant counties, on farms located along Highway 401 and farms in the vicinity of the Greater Toronto Area.

Yields can be affected by family tradition of strawberry production, and grower's will to adopt new technologies in strawberry production. It is interesting to note that the average strawberry yields of $10,000 \mathrm{~kg} /$ ha or higher were achieved on farms with good working relations with research institutions. The average yield on farms with a tradition in strawberry production was from $7,840 \mathrm{~kg} /$ ha to $16,800 \mathrm{~kg} /$ ha per season (Table 1). The lowest yields were recorded on farms with strawberries as a new crop within the production program. The survey data suggest that the main reason for yield reduction is lack of adequate weed, pest and disease management. The pesticide regime of strawberries is intensive and complex, which requires excellent knowledge of strawberry production technology to secure adequate plant protection and safe fruit. 
The achieved yields are somewhat lower or within the range reported in literature. In a variety trial in Ontario, reported yields from $2,900 \mathrm{~kg} / \mathrm{ha}$ to $20,600 \mathrm{~kg} / \mathrm{ha}$ per season. The reported size of the yields was highly dependent of experimental location. Handley and Dill (2009) examined varietal phonological properties of several varieties grown in eastern part of United States of American.

The authors reported yields from $6,543 \mathrm{~kg} / \mathrm{ha}$ to $18,391 \mathrm{~kg} /$ ha per season, while Stevens et al. (2011), in the same region, recorded yields $13,700 \mathrm{~kg} / \mathrm{ha}$. It is important to note that yields reported on farms are about $80 \%$ of yields achieved in experimental conditions.

\section{Cost of Production}

The cost of short-day strawberry production includes the following elements: equipment, labor, external services, materials, overhead and miscellaneous costs (cooling and transport of berries). Each cost element is further categorized within four cost categories: 1) field establishing cost, 2) cost of planting and care of young plants after planting, 3) cost of care and harvest in first production year and 4) cost of care and harvest in second production year.

The total cost to produce short-day strawberries is 54,370 \$CAD/ha (Table 2). The cost of care and harvest in first production year was $20,812 \$ C A D /$ ha and the cost of care and harvest in second production year was $19,930 \$ C A D /$ ha, which comprised $69.42 \%$ of the total. The lowest cost was recorded in the pre-plans year at $8.13 \%$, while the cost of planting and care of young plants after planting accounted for $22.45 \%$.

Table 2. Total cost of short-day strawberry production ( $\$ \mathrm{CAD} / \mathrm{ha})$

\begin{tabular}{|l|r|r|r|r|r|r|}
\hline \multicolumn{1}{|c|}{ Cost } & Pre-plans & \multicolumn{1}{c|}{$\begin{array}{c}\text { Planting and } \\
\text { care }\end{array}$} & $\begin{array}{l}\text { Harvest and } \\
\text { care in 1 } \\
\text { year }\end{array}$ & $\begin{array}{c}\text { Harvests } \\
\text { and care in } \\
\mathbf{2}^{\text {nd }} \text { year }\end{array}$ & Total & $\begin{array}{c}\text { Participation } \\
\mathbf{( \% )}\end{array}$ \\
\hline Equipment & 611 & 2,132 & 1,415 & 1,174 & 5,332 & 9.80 \\
\hline Labor & 258 & 3,360 & 10,531 & 8,571 & 22,720 & 41.79 \\
\hline Custom services & 398 & 399 & 277 & 67 & 1,141 & 2.10 \\
\hline Materials & 3,154 & 4,951 & 4,983 & 3,815 & 16,903 & 31.09 \\
\hline Overhead cost & - & 1,364 & 1,689 & 1,660 & 4,713 & 8.67 \\
\hline Miscellaneous & - & - & 1,917 & 1,645 & 3,562 & 6.55 \\
\hline Total & 4,421 & 12,206 & 20,812 & 16,931 & 54,370 & 100.00 \\
\hline Participation (\%) & 8.13 & 22.45 & 38.28 & 31.14 & 100.00 & - \\
\hline
\end{tabular}

Source: Authors calculation based on survey 28 producers strawberries in South-western Ontario

Overall materials and labor costs accounted for almost $3 / 4$, while equipment, custom cervices, overhead and miscellaneous costs made up remaining $1 / 4$ of the total cost to growshort day strawberries under matted-row system. 


\section{Financial result}

Financial result for short-day strawberry production is calculated as the difference between total income in the first and second harvest years and total strawberry production cost. The income for first and second harvest years was calculated as a sum of income for each channel of strawberry sale for both years, while the income for each channel of sale is the product of average price received and its portion in the total yield (Table 3 ).

Table 3. Total income per channel of sale and total cost (\$CAD/kg)

\begin{tabular}{|l|r|r|r|r|}
\hline \multicolumn{1}{|c|}{ Indicators } & \multicolumn{1}{c|}{$\begin{array}{c}\text { U-Pick* } \\
\mathbf{( 2 5 \% )}\end{array}$} & $\begin{array}{c}\text { Wholesale } \\
\mathbf{( 4 5 \% )}\end{array}$ & $\begin{array}{c}\text { Retail** } \\
\mathbf{( 3 0 \% )}\end{array}$ & \multicolumn{1}{c|}{ Total } \\
\hline 1.Total income: both years & & & & 76,671 \\
\hline -Income in first year & 8,915 & 15,084 & 17,331 & 41,330 \\
\hline -Income in second year & 7,623 & 12,898 & 14,820 & 35,341 \\
\hline 2. Total cost & & & & 54,370 \\
\hline NET INCOME (1-2) & & & & 22,300 \\
\hline
\end{tabular}

Source: Authors calculation based on survey 28 producers strawberries in South-western Ontario Note: * Customers pick strawberries; ** Farm gate and local farmer's market sale.

The direct sale at the farm's gate and local farmer's market accounted for only $30 \%$ in total strawberry sale, but it achieved highest income due to high sale prices. The total sale value in both years, from all channels of sale, was 76,671 \$CAD/ha. The income in the first and second year was 41,330 and 35,341 \$CAD/ha, respectively. The total expense to grow shortday strawberries was $54,371 \$ \mathrm{CAD} / \mathrm{ha}$ (sum of expenses in pre harvest year, planting and care of young plants after the planting and care and harvests in both years), (Table 3). Strawberries are an intensive crop. Sales per hectare are high, but costs are also high. However, it still adds considerably to the total earning power of the whole farm business at 22,300 \$CAD/ ha. Therefore, average net revenue or profit, which is the earnings for risk and management, amounted $29.10 \%$ of the sales value of the crop. This is comparable with that for other fruit crops, even to the earnings by most annual cash crops.

The average profit is comparable to results achieved by other researchers. Garwood (1998) reported that average net return of strawberries grown in matted-row production systems in North Carolina was 14,424 \$US/ha. The net return in this study was 30 to $75 \%$ higher compared to returns reported by DeMarree (1998) in United States of America, Combe and Fisher (1999) in Ontario. However, achieved net revenue was 64\% lower compared to revenues reported by Stevens et al. (2011) in United States of America. It is important to note that their financial analysis did not include overhead, custom services and miscellaneous costs. The cost of material and labour was two to three times lower compared to Ontario conditions.

\section{Conclusion}

The establishment and production costs of short-day strawberries grown under matted-rows system were $54,370 \$ C A D / h$. The average costs of pre plant operations were $4,421 \$ C A D /$ 
ha. The fixed costs accounted for $9.34 \%$. The materials made up $71.34 \%$ of the total pre plant costs. The cost of operations to maintain and protect soil quality and structure comprised $24.49 \%$. Manure application was the highest cost item $(11.88 \%)$, while soil sampling and analysis the lowest (1.83\%). Costs for planting and care of young plants were 12,206 \$CAD/ ha. Variable costs accounted for $80.49 \%$ of the total.

The materials and labor costs comprised $40.53 \%$ and $27.53 \%$ of the variable cost, respectively. The costs of pre-plans and planting and after planting operations costs made up $30.58 \%$, or $16,627 \$ C A D /$ ha of the cost to grow short-day strawberries under matted-row system. The costs of regular care and harvest in first production year were 20,812 \$CAD/ha. The variable costs accounted for $80.49 \%$ of the total. The labor and material costs comprised $56.83 \%$ and $26.89 \%$ of the variable cost, respectively. The costs of regular care and harvest in second production year were $16,931 \$ \mathrm{CAD} / \mathrm{ha}$. The variable costs accounted for $87.83 \%$ of the total. The labor and material costs made up $57.70 \%$ and $25.68 \%$ of the variable cost, respectively.

The total income of short-day strawberries grown in a matted-row system was 76,671 \$CAD/ ha. The income in the first and second production years were 41,331 \$CAD/ha and 35,341 $\$ C A D /$ ha, respectively. The total production costs were 54,370 \$CAD/ha (the sum of preplans, planting and care of young plants, care and harvest in the first production year and care and harvest in the second harvest year costs). Strawberries are an intensive crop in terms of labor and resources. The sales per hectare are high, but costs are also high. However, net revenue analysis showed that growers in Ontario at average yield of $15,772 \mathrm{~kg} / \mathrm{ha}$ achieved profit of $22,300 \$ C A D / h a$, which is $29.10 \%$ of the sales value of the crop.

\section{Acknowledgements}

The paper is part of the research projects number: TR31058 - Drying of Organic and Integrated Fruits and Vegetables Drying Technology; 46009 - Promotion and development of hygienic and technological processes in the production of foods of animal origin in order to obtain high-quality and safe products competitive on the world market; and 179028 - Rural labor markets and rural economy of Serbia - the diversification of income and poverty reduction, funded by the Ministry of Education and Science of the Republic of Serbia, in period 2011-2014.

\section{Literature}

1. Ballington, J. R., Poling, B., Olive, K. (2008): Day-neutral strawberry production for season extension in the midsouth, HortScience, vol. 43(7), pp. 1982-1986.

2. Combe, M. J., Fisher, P. (1999): Estimated establishment cost and cost of production for raspberries and strawberries in Ontario, Ontario Ministry of Agriculture, Food and Rural Affairs, p. 22.

3. Darnell, L. R., Cantliffe, J. D., Kirschbaum, S. D., Chandler, K. C. (2003): The physiology of flowering in strawberry, In: Janick, J. (ed.) Horticultural Reviews, vol. 28, pp. 325349, John Wiley \& Sons. 
4. DeMarree, A. (1998): Budgeting, p.p. 118-129, In: Strawberry production guide: for the northeast, Midwest, and eastern Canada, Pritts, M. P., Handley, D. (ed.), NRAES-88, Cooperative extension.

5. Garwood, T. (1998): An economic analysis of matted row, plasticulture and greenhouse production systems in North Carolina, MS thesis, N.C. State Univiversity, Raleigh.

6. Handley, D. T., Dill, J. F. (2009): A strawberry integrated pest management program for a cold climate, direct-marketing region, ISHS Acta Horticulturae 842: VI International Strawberry Symposium, pp. 645-648.

7. Lieten, F. (2003): Protected cultivation of strawberries in cental Europe, In Norman F. Childers (ed.) The strawberry: A book for Growers, Others. Dr Norman F. Childers Publications, Gainesville, FL, pp. 190-194.

8. Milić, D., Sredojević, Z. (2010): Profitabilnost proizvodnje jagode vertikalnog sistema uzgoja, Zbornik radova, Agrosym, Jahorina, Poljoprivredni fakultet, Istočno Sarajevo i Poljoprivredi fakultet, Beograd, str. 111-116.

9. Milić, D., Sredojević, Z., Jeločnik, M. (2008): Utvrđivanje gornje granice investiranja u podizanje zasada višnje, Ekonomika poljoprivrede, IEP, Beograd, vol. 55, no. 4, str. 379-387.

10. Pritts, M. P, Castaldi, A. M. (1990): Assessing the economic implication of research on production practices for strawberry crops, In Dale, A., Luby, J. J. (eds.): Proceedings of the $3^{\text {rd }}$ NASC, Houston, Texas, pp. 237-243.

11. Rowley, D., Black, B. L., Drost, D., Feuz, D. (2010): Early-season extension using junebearing 'Chandler'strawberry in high-elevation high-tunnels, HortScience, vol. 45(10), pp. 1464-1469.

12. Safley, D. C., Poling, E. B., Wohlgenant, K. M., Sydorovych, O., Wiliams, F. R. (2004): Producing and marketing strawberries for direct market operation, HortTechnology, vol. 14(1), pp. 124-135.

13. Sredojević, Z., Mojsijev, D. (2013): Farm.Soft S.20.10-Agromix-softvare for recording agricultural farm business operations: an example of good practice in Serbia, Thematic procedings - Internatuional Scientific Conference Sustainable agriculture and rural development in terms of the Republic of Serbia strategic goals realization within the Danube region - achieving regional competitiveness, IAE, BSAAE, Belgrade, (B.E.N.A), Thessaloniki et al., Belgrade, pp. 798-815.

14. Stevens, D. M., Black, L. B., Lea-Cox, D. J., Feuz, D. (2011): Horticultural and economic considerations of three cold-climate strawberry production, HortScience, vol. 46(3), pp. 445-451.

15. Wang, S. J., Lin, H. S. (2000): Antioxidant activity in fruits and leaves of blackberry, raspberry and strawberry varies with cultivar and developmental stage, J. Agric. Food Chem., vol. 48, pp. 140-146.

Website:

16. Ontario Berry Growers Association (OBGA), available at: http://ontarioberries.com/ site/about-obga.html 


\title{
OSTVARENI FINANSIJSKI REZULTAT U PROIZVODNJI JAGODE KRATKOG DANA
}

\author{
Dragan Galič́, Dušan Milćc ${ }^{4}$, Zorica Sredojevićc
}

\begin{abstract}
Rezime
U uslovima kontinentalne klime jugo-zapadnog Ontarija u kojima su leta kratka i vruća, a zime hladne, dominantno je gajenje jagode kratkog dana u redovima na otvorenom polju. $U$ strukturi proizvodnje učestvuju rane, srednje i kasne sorte, što omogućava berbu od 5 do 7 nedelja. Ukupna eksploatacija jagodnjaka je dve godine. Troškovi zasnivanja i proizvodnje jagode kratkog dana u prvoj i drugoj godini posle sadnje iznose ukupno 54.370 \$CAD/ha. Troškovi nege i berbe u prvoj godini iznose 20.812 \$CAD/ha, a troškovi nege i berbe u drugoj godini su $16.930 \$ C A D / h a$, pri čemu učestvuju sa 69,42\% u strukturi ukupnih troškova zasnivanja i redovne proizvodnje jagode. Najniža ulaganja su pri zasnivanju zasada sa učešćem od 8,13\%, dokje udeo troškova sadnje i nege zasada u ukupnim ulaganjima 22,45\%. Ukupan prihod u proizvodnji jagode kratkog dana je 76.671 \$CAD/ha (41.330\$CAD u prvoj godini i 35.341 \$CAD/ha u drugoj godini). Prema tome, i pored visokih ulaganja po jedinici površine kod jagoda kratkog dana, uz prosečan prinos od $15.772 \mathrm{~kg} / \mathrm{ha}$, ostvaruje se profit od $22.301 \$ C A D / h a$.
\end{abstract}

Ključne reči: jagode kratkog dana, troškovi proizvodnje, vrednost proizvodnje, finansijski rezultat.

4 Mr Dragan Galić, Univerzitet Guelph, Departman biljne poljoprivrede, Box 587, Simcoe, N3Y 4N5, ON, Canada, Telefon: 00151942822 45, E-mail: dgalic@uoguelph.ca

5 Dr Dušan Milić, redovni professor, Univeryitet u Novom Sadu, Poljoprivredni fakultet, Trg Dositeja Obradovića 8, 21000 Novi Sad, Srbija, Telefon: +381 21485 32 30, E-mail: milic@polj.uns.ac.rs

6 Dr Zorica Sredojević, redovni profesor, Univerzitet u Beogradu, Poljoprivredni fakultet, Institut za agroekonomiju, Nemanjina 6, 11080 Beograd, Srbija, Telefon: +381 112615 315, E-mail: zokas@agrif.bg.ac.rs

EP 2014 (61) 4 (851-859) 